Volume 12, Nomor 2, April 2021, p.069-082

Faculty of Law, Universitas Kristen Maranatha

ISSN: 2085-9945 I e-ISSN: 2579-3520

Nationally Accredited Journal by SINTA

\title{
PERSPEKTIF HUKUM ISLAM MENGENAI PRAKTIK GHARAR DALAM TRANSAKSI PERBANKAN SYARIAH
}

\author{
Hadist Shohih, Ro'fah Setyowati
}

Fakultas Hukum, Universitas Diponegoro

hadistsho96@gmail.com,rofahundip@gmail.com

Submitted: 2021-01-22 | Reviewed: 2021-03-13 | Accepted: 2021-04-13

How to cite: Hadist Shohih, Ro'fah Setyowati. "Perspektif Hukum Islam Mengenai Praktik Gharar dalam Transaksi Perbankan Syariah”. Dialogia Iuridica: Jurnal Hukum Bisnis dan Investasi, Vol. 12, No. 2, (2021): 069082.

DOI:

https://doi.org/10.28932/di.v12i2.3323

\begin{abstract}
Islamic law prohibits the making of a contract in an uncertain business transaction and causes the other party to suffer losses and the other party to gain, so this becomes Gharar. This study aims to analyze Gharar's practices in banking and investment in Indonesia. The research method used is juridical normative, using secondary data, which is obtained through literature study, the analytical approach used in this research is descriptive analytical. The results of the study concluded that Gharar should be avoided in banking and investment institutions because Gharar's practice has the potential to occur in all (commercial) business contracts. Where there is incomplete information due to the uncertainty of the two transacting parties and even changing something that should be certain to be uncertain. So that in order to realize a good transaction system according to Islam, support from Muslims is needed, namely by applying the concept of investment in Islam. Islamic financial transactions must be constructed carefully and avoid things that are prohibited by Islam.
\end{abstract}

Keywords: Banking; Gharar; Investment; Transaction. 


\section{PENDAHULUAN}

Hukum Islam adalah hukum yang bersifat universal, karena merupakan bagian dari agama Islam yang universal sifatnya. Maka otomatis hukum Islam berlaku bagi orang Islam di manapun ia berada, apapun nasionalitasnya. Hukum Islam adalah bagian dari hukum nasional adalah hukum yang berlaku bagi bangsa tertentu di suatu negara nasional tertentu. ${ }^{1}$ Kedudukan hukum Islam dalam hukum nasioanal adalah bahwa hukum Islam menjadi bagian dalam hukum nasioanal dan berlaku penuh bagi umat Islam. Artinya semua umat Islam harus tunduk pada ajaran hukum Islam, hal ini sejalan dengan pengamalan sila pertama Pancasila yang berbunyi Ketuhanan Yang Maha Esa, sila ini mengamanatkan bahwa bangsa Indonesia harus tunduk pada ajaran agamanya masing-masing. Khusus mengenai hukum Islam, ada 3 (tiga) aspek yang menjadi pondasi dalam ajaran hukum Islam, yang pertama aspek aqîdah (iman), yang kedua aspek syariah (Islam), dan yang ketiga yaitu aspek akhlak (ihsan). ${ }^{2}$ Berdasarkan 3 (tiga) aspek yang menjadi pondasi ajaran hukum Islam tersebut, bisa diketahui bahwa dalam ajaran hukum Islam tidak hanya mengutamakan atau mengandalkan ibadah semata, namun juga harus memperhatikan aspek yang bersifat Muamalah, yang artinya hal yang mengatur hubungan manusia denga sesama manusia lain (hablum minannas), yang meliputi berbagai aspek, yaitu aspek hak (the right) dalam perspektif hukum hingga aspek ekonomi, yang dalam konteks ini adalah Perbankan Syariah.

Aspek yang bersifat muamalah, dalam konteks perekonomian, hukum Islam menekankan pada unsur etika dalam tataran praktiknya. Unsur etika dalam hukum Islam menjadi landasan bagi praktik penerapan hukum Islam dalam kehidupan bermasyarakat, berbangsa, dan bernegara. Etika menduduki posisi yang paling dasar sehingga semua jaran, semua hukum, semua prilaku dalam Islam haruslah berlandaskan pada unsur etika. Ajaran hukum Islam secara tegas melarang adanya unsur eksploitasi ekonomi yang berupa riba atau bunga uang dan transaksi-transaksi yang belum diketahui kejelasannya, atau yang dikenal dengan istilah Gharar. ${ }^{3}$ Hukum Islam melarang secara tegas transaksi bisnis yang mengandung riba atau bunga uang, hukum Islam hanya membolehkan transaksi bisnis yang dilandasi dengan adanya "bagi hasil". Hal pembeda antara sistem bunga dan bagi hasil adalah pada perjanjiannya atau Akad nya. Jika bunga yang menentukan adalah Kreditornya sedangkan sistem bagi hasil, besaran bagi hasilnya disepakati oleh Kreditor dan Debitornya. Transaksi bisnis dalam Perbankan Syariah, harus dilandasi oleh ajaran hukum Islam. Karakteristik sistem perbankan syariah yang beroperasi berdasarkan prinsip bagi hasil memberikan alternatif sistem perbankan yang saling menguntungkan bagi masyarakat dan bank, serta menonjolkan aspek keadilan dalam bertransaksi, investasi yang beretika, mengedepankan nilai-nilai kebersamaan dan persaudaraan dalam berproduksi, dan menghindari kegiatan spekulatif dalam bertransaksi keuangan. Dengan menyediakan beragam produk serta layanan jasa perbankan yang beragam dengan skema keuangan yang lebih bervariatif, perbankan syariah menjadi alternatif sistem

\footnotetext{
${ }^{1}$ Ajub Ishak, "Posisi Hukum Islam Dalam Hukum Nasional Di Indonesia", Jurnal Al-Qadau, 4.1 (2017), 12-27. Hlm. 12.

2 Siti Amaroh, "Tanggung Jawab Sosial Bank Syariah Terhadap Stakeholder Dalam Perspektif Maqâshid Syarî’ah", Ahkam, 16.1 (2016), 23-38. Hlm. 32.

${ }^{3}$ Efa Rodiah Nur, "Riba Dan Gharar: Suatu Tinjauan Hukum Dan Etika Dalam Transaksi Bisnis Modern", Jurnal AL-'ADALAH, 12.3 (2015), 647-662, hlm. 651.
} 
Volume 12, Nomor 2, April 2021

perbankan yang kredibel dan dapat dinimati oleh seluruh golongan masyarakat Indonesia tanpa terkecuali. ${ }^{4}$

Dalam konteks pengelolaan perekonomian makro, meluasnya penggunaan berbagai produk dan instrumen keuangan syariah akan dapat merekatkan hubungan antara sektor keuangan dengan sektor riil serta menciptakan harmonisasi di antara kedua sektor tersebut. Semakin meluasnya penggunaan produk dan instrumen syariah disamping akan mendukung kegiatan keuangan dan bisnis masyarakat juga akan mengurangi transaksi-transaksi yang bersifat spekulatif, sehingga mendukung stabilitas sistem keuangan secara keseluruhan, yang pada gilirannya akan memberikan kontribusi yang signifikan terhadap pencapaian kestabilan harga jangka menengah-panjang. ${ }^{5}$

Pada tataran praktiknya secara umum pelaksanaan muamalah yang berarti transaksi bisnis, akan menghadapi 2 (dua) hal yaitu akan mendapatkan keuntungan ataupun bisa mendapatkan kerugian. Tentunya semua pihak dalam melakukan transaksi bisnis akan mengharapkan keuntungan, namun untuk mendapatkan keuntungan tersebut harus dilakukan atau ditempuh dengan cara yang benar menurut standard moral dan hukum. ${ }^{6}$ Standard moral dan hukum yang dimaksud bahwa keuntungan dalam berbisnis harus juga diperoleh dengan cara yang sesuai dengan ajaran agama, kesusilaan dan hukum. Perlu ditekankan bahwa hukum Islam tidak melarang suatu akad yang hanya terkait dengan risiko dari sesuatu ketidakpastian. Namun apabila risiko tersebut sebagai upaya untuk membuat satu pihak mendapatkan keuntungan, sedangkan di sisi lain pihak lain mengalami kerugian maka hal itulah yang dilarang dalam ajaran hukum Islam dan hal tersebut akan mengarah pada Gharar. ${ }^{7}$ Apabila sustu transaksi bisnis sudah mengarah ke pada Gharar maka hal ini tentu bertentangan dengan ajaran hukum Islam. "Menurut Ibnu Taimiyah sudah jelas bahwa Allah Swt dan Rasulullah Saw, tidak melarang setiap jenis risiko. Begitu juga tidak melarang semua jenis transaksi yang kemungkinan mendapatkan keuntungan atau kerugian ataupun netral (tidak untung dan tidak rugi). Yang dilarang dari kegiatan semacam itu ialah memakan harta orang lain secara tidak benar, bahkan bila tidak terdapat risiko, bukan risikonya yang dilarang". 8

Di era modern seperti saat ini, yang memunculkan istilah baru yaitu industri 4.0, banyak memunculkan berbagai transaksi bisnis yang memanfaatkan teknologi informasi yang dilakukan seacara online. ${ }^{9}$ Perkembangan teknologi informasi sangat berdampak dalam berbagai sektor kehidupan masyarakat Indonesia. Salah satu sektor yang sangat terdampak adalah sektor Perbankan Syariah. Sektor Perbankan Syariah yang dulunya hanya bisa dilakukan secara tatap muka, harus antri ke teller bank, agar bisa melakukan transaksi keuangan namun sekarang adanya perkembangan teknologi informasi, semua transaksi bisnis Perbankan

\footnotetext{
${ }^{4}$ Ismail, Perbankan Syariah, Jakarta: Kencana, 2011, hlm. 54.

5 Zubairi Hasan, Undang-Undang Perbankan Syariah Titik Temu Hukum Islam Dan Hukum Nasional, Jakarta: PT Raja Grafido Persada, 2009.

${ }^{6}$ Irsan Rahman Ali Mansyur, "Penegakan Hukum Perlindungan Konsumen Sebagai Upaya Peningkatan Mutu Produksi Nasional", Jurnal Pembaharuan Hukum, 2.1 (2015), 1-18. hlm. 4.

${ }^{7}$ Evan Hamzah Muchtar, "Muamalah Terlarang: Maysir Dan Gharar", Jurnal Asy-Syukriyyah, 18.2 (2017), 8094. hlm. 84.

${ }^{8}$ Muchtar, Ibid. hlm. 83.

${ }^{9}$ Nur Adhim Kornelius Benuf, Rinitami Njatrijani, Ery Agus Priyono, "Pengaturan Dan Pengawasan Bisnis Financial Technology Di Indonesia", Dialogia Iuridica: Jurnal Hukum Bisnis Dan Investasi, 11.2 (2020), 46-69. hlm. 47
} 
Volume 12, Nomor 2, April 2021

Syariah tersebut bisa dilakukan melalui mobile phone setiap orang. ${ }^{10}$ Ditambah lagi dengan adanya fenomena Covid-19 menjadikan transaksi bisnis Perbankan Syariah secara online banyak dilakukan masyarakat di dunia pada umumnya dan masyarakat di Indonesia pada khususnya. Fenomena Covid-19 menjadikan masyarakat Indonesia dibatasi aktivitasnya di luar rumah, hal ini menyebabkan aktivitas yang sebelumnya bisa dilakukan di luar rumah saat ini harus dilakukan di dalam rumah atau dilakukan secara online, seperti misalnya rapat online, belajar online, dan bertransaksi online. ${ }^{11}$

Transaksi bisnis Perbankan Syariah secara online ditengarai berkiblat pada transaksi bisnis ala barat, sehingga pelaksanaan Perbankan Syariahnya juga berkiblat pada budaya barat, dimana memperbolehkan adanya bunga atau riba dalam setiap transaksinya, tentu hal ini bertentangan dengan hakikat ajaran hukum Islam. Transaksi bisnis adalah aktivitas atau peristiwa yang dapat diukur dalam bentuk moneter dan yang mempengaruhi posisi keuangan atau operasi entitas bisnis. Transaksi bisnis berpengaruh pada elemen akuntansi manapun baik aset, kewajiban, modal, pendapatan, dan biaya. ${ }^{12}$ Praktik transaksi bisnis berkaitan dengan adat dan kebiasaan masyarakat setempat. ${ }^{13}$ Kebiasaan masyarakat barat sungguh sangat bertolak belakang dengan kebiasaan bangsa timur termasuk Indonesia. Bangsa barat lebih liberalis sedangkan bangsa Indonesia lebih kepada sosialis. Namun masih ada suatu perdebatan di kalangan akademisi yang masih belum menyatukan pandangan mengenai, apakah bunga uang itu Gharar atau bukan? "Kaum neo-Revivalis berpedoman bahwa bunga adalah diharamkan, karenanya mereka menuntut penghapusan bunga.

Sedangkan kaum modernis berpendapat bahwa tidak semua bentuk bunga adalah riba/diharamkan. Mereka mengatakan hanya bunga yang dinilai tidak adil yang bisa dikatakan riba. Bahkan masalah riba-pun para ulama masih berbeda pendapat, ada yang mengatakan riba haram kalau bersifat eksploitasi (yang berlebihan). Sedangkan yang lain mengatakan, semua riba haram baik itu sedikit ataupun banyak". ${ }^{14}$ Riba adalah suatu kegiatan pengambilan nilai tambah yang memberatkan dari sebuah akad perekonomian, seperti jual beli maupun utang piutang. Riba juga merujuk pada kelebihan dari jumlah uang pokok yang dipinjamkan oleh pemberi pinjaman ke orang yang meminjam. Dalam pengertian bahasa, riba memiliki arti tambahan atau dalam bahasa Arab disebut sebagai azziyadah. Tambahan yang dimaksud dalam pengertian riba adalah usaha haram yang merugikan salah satu pihak dalam proses transaksi.

Adanya pendapat yang menyatakan bahwa pemberian bunga dalam transaksi Perbankan Syariah di Indonesia, belum memiliki kedudukan yang jelas, apakah termasuk bentuk muamalah modern atau bukan, hal ini menjadikannya perlu untuk diketahui status hukumnya. Timbulnya perdebatan semacam ini sejak 1930-an hingga sekarang. Yang menjadi

\footnotetext{
10 and Bella Gita Novalia. Muzdalifa, Irma, Inayah Aulia Rahma, "Peran Fintech Dalam Meningkatkan Keuangan Inklusif Pada UMKM Di Indonesia (Pendekatan Keuangan Syariah)", Jurnal Masharif Al-Syariah: Jurnal Ekonomi Dan Perbankan Syariah, 3.1 (2018), 1-24. hlm. 7.

${ }^{11}$ Kornelius Benuf, "Urgensi Kebijakan Perlindungan Hukum Terhadap Konsumen Fintech Peer To Peer Lending Akibat Penyebaran Covid-19", Jurnal RechtsVinding, 9.2 (2020), 203-217. hlm. 210.

${ }^{12}$ Hendro Nugroho, "Perlindungan Hukum Bagi Para Pihak Dalam Transaksi Pinjaman Online", JUSTITIA: Jurnal Ilmu Hukum Dan Humaniora, 7.2 (2020), 328-334. hlm. 331.

${ }^{13}$ Dyah Pratiwi Agus Santoso, "Tanggung Jawab Penyelenggara Sistem Elektronik Perbankan Syariah Dalam Kegiatan Transaksi Elektronik Pasca Undang-Undang Nomor 11 Tahun 2008 Tentang Informasi Dan Transaksi Elektronik", Jurnal Legislasi, 5.4 (2018), 74-88. hlm. 77.

${ }^{14}$ Nadratuzzaman Hosen, "Analisis Bentuk Gharar Dalam Transaksi Ekonomi", Al-Iqtishad, 1.1 (2009), 53-64. hlm. 54
} 
landasannya adalah cara berpikir para cendekiawan yang tekstual dan kontekstual. ${ }^{15}$ Berawal dari perdebatan-perdebatan di atas, maka penulis tertarik untuk mengangkat legal issue yaitu bagaimana Perspektif Hukum Islam terhadap praktik Gharar dalam Perbankan Syariah di Indonesia? Dalam penelitian ini akan dibahas mengenai Terminologi Gharar dalam hukum Islam, Gharar dalam Praktik Perbankan Syariah di Indonesia. Penelitian ini diharapkan mampu memberikan penjelasan yang komprehensif mengenai Gharar dalam transaksi bisnis Perbankan Syariah di Indonesia dengan berlandaskan pada perspektif hukum Islam, agar nilainilai religius dalam hukum Islam tetap terjaga dan tetap terwudjud dalam praktiknya.

Metode pendekatan yang digunakan dalam penelitian ini adalah pendekatan yuridis normatif. Penelitian ini mengkaji permasalahan Gharar dalam Perbankan Syariah di Indonesia, dengan berlandaskan pada hukum Islam. Data hukum yang digunakan adalah data sekunder, yang diperoleh melalui studi kepustakaan. ${ }^{16}$ Spesifikasi penelitian dalam penulisan ini bersifat deskriptif analisis, yaitu suatu analisis dengan menggambarkan objek penelitian. Data sekunder merupakan data pengumpulannya dilakukan secara tidak langsung, yaitu dengan studi kepustakaan, ${ }^{17}$ guna mendapatkan landasan teoritis dan beberapa pendapat, maupun tulisan para ahli dan juga untuk memperoleh informasi, baik dalam bentuk ketentuan formal, maupun data melalui naskah ilmiah yang ada.

\section{PEMBAHASAN}

\section{Terminologi Gharar dalam Hukum Islam}

Gharar secara etimologi berarti resiko atau bahaya. Asal kata Gharar dari bahasa Arab yaitu "Gharar, taghrir atau yaghara yang berarti menipu orang dan membuat orang tertarik untuk berbuat kebatilan, salah satu bentuk Gharar ialah menukarkan sesuatu benda dengan pihak lain dengan adanya unsur yang tidak diketahui atau tersembunyi untuk tujuan yang merugikan atau membahayakan". ${ }^{18}$ Gharar yaitu ketidakpastian dalam transaksi yang diakibatkan dari tidak terpenuhinya ketentuan syariah dalam transaksi tersebut. Dampak dari transaksi yang mengandung Gharar adalah adanya pendzaliman atas salah satu pihak yang bertransaksi sehingga hal ini dilarang dalam Islam. Beberapa kategori unsur Gharar antara lain dari segi kuantitas tidak sesuainya timbangan atau takaran, kemudian dari siis kualitas terdapat ketidakjelasan pada kualitas barang, selanjutnya dari sisi harga adanya dua harga dalam satu transaksi, dan yang terakhir dari sisi waktu yaitu terdapat ketidakjelasan pada waktu penyerahan. Ketidakpastian yang muncul akibat tidak terpenuhinya ketentuan syariah dalam suatu transaksi, maka ketidakpastian tersebut merupakan gharar yang dilarang oleh syariat. Adapun Ketidakpastian yang tetap muncul setelah seluruh ketentuan syariah terpenuhi dalam suatu transaksi, maka ketidakpastian tersebut merupakan sunnatullah yang tidak boleh

\footnotetext{
15 Putri Nova Khairunisa, "Etika Bisnis Dalam Islam Terhadap Transaksi Terlarang Riba Dan Gharar", LABATILA: Jurnal Ilmu Ekonomi Islam, 3.1 (2019), 23-40. hlm. 30.

${ }^{16}$ Muhamad Azhar Kornelius Benuf, "Metodologi Penelitian Hukum Sebagai Instrumen Mengurai Permasalahan Hukum Kontemporer", Jurnal Gema Keadilan, 7.1 (2020), 20-33. hlm. 24.

17 Suteki Galang Taufani, Metodologi Penelitian Hukum (Filsafat, Teori, Dan Praktik), Depok: Rajawali Pers, 2017, hlm. 35.

${ }^{18}$ Ar Royyan Ramly, "The Concept of Gharar and Masyir and It's Application to Islamic Financial Institutions", International Journal of Islamic Studies and Social Sciences, 1.1 (2019), 1-14. hlm. 4.
} 
dihilangkan, namun dapat dikelola. Bebrapa Ulama fiqih memberikan pandangannya terhadap Gharar, adapun Ulama-Ulama tersebut antara lain:

a. "Imam as-Sarakhsi, dari mazhab Hanafi, menyatakan Gharar yaitu sesuatu yang tersembunyi akibatnya".

b. "Imam al-Qarafi, dari mazhab Maliki, mengemukakan bahwa Gharar adalah suatu yang tidak diketahui apakah ia akan diperoleh atau tidak".

c. "Imam Shirazi, dari mazhab Syafi'i, mengatakan Gharar adalah sesuatu yang urusannya tidak diketahui dan akibatnya tersembunyi"

d. "Ibnu Taimiyah menyatakan Gharar tidak diketahui akibatnya"

e. "Ibnul Qoyyim berkata bahwa Gharar adalah sesuatu yang tidak dapat diukur penerimaannya baik barang tersebut ada ataupun tidak ada, seperti menjual kuda liar yang belum tentu bisa di tangkap meskipun kuda tersebut wujudnya ada dan kelihatan".

f. "Ibnu Hazm mendefinisikan Gharar dengan suatu keadaan dimana ketika pembeli tidak tahu apa yang dia beli atau penjual tidak tahu apa yang dia jual". ${ }^{19}$

Sedangkan Sayyid Sabiq dalam fiqh sunnah memberikan pengertian Gharar adalah "penipuan yang mana diperkirakan menyebabkan tidak ada kerelaan jika diteliti". Selanjutnya Hashim Kamali menyatakan "Gharar berarti penipuan”. Ada banyak pengertian yang bisa ditemukan dalam berbagai literatur mengenai pengertian Gharar, secara yuridis Gharar bisa dijelaskan sebagai berikut: "Pertama, Gharar yang hanya terkait dengan kasus yang meragukan atau ketidakpastian, misalnya saja apakah sesuatu itu akan terjadi atau tidak, Kedua, Gharar dapat diterapkan pada sesuatu yang tidak diketahui, bukannya yang meragukan, Ketiga, Gharar yang merupakan kombinasi dari dua kategori, yakni baik yang tidak diketahui maupun yang meragukan sebagaimana yang didefinisikan oleh As-Sarahasi yang berkata Gharar akan didapati apabila konsekuensi atau akibatnya itu tidak terungkap dan definisi yang ketiga ini yang banyak diminati di dalam hukum Islam". ${ }^{20}$

Ada 2 (dua) konsep Gharar yaitu, "pertama, adalah unsur risiko yang mengandung keraguan, probabilitas dan ketidakpastian secara dominan. Kedua, unsur meragukan yang dikaitkan dengan penipuan atau kejahatan oleh salah satu pihak terhadap pihak lainnya". ${ }^{21}$ "Alquran dengan tegas telah melarang semua transaksi bisnis yang mengandung unsur kecurangan dalam segala bentuk terhadap pihak lain, hal itu mungkin dalam segala bentuk penipuan atau kejahatan, atau memperoleh keuntungan dengan tidak semestinya atau risiko yang menuju ketidakpastian di dalam suatu bisnis atau sejenisnya. Hal tersebut termuat di dalam Q.s. al-An'am: 152”. “Gharar hukumnya dilarang dalam Islam, oleh karenanya melakukan transaksi atau memberikan syarat dalam akad yang ada unsur Ghararnya hukumnya tidak boleh. Sebagaimana hadis menyebutkan: Rasulullah Saw. melarang jual beli yang mengandung Gharar. (HR. Bukhari Muslim)".22 "Dalam fikih Gharar dimaklumi apabila

\footnotetext{
${ }^{19}$ Wahbah Al-Zuhayli, Al-Fiqh Al-Islami Wa Adillatuh, Juz 5, Damaskus: Dar al-Fikr, 2004, hlm. 3408

${ }^{20}$ Ramly. Op Cit, hlm 5

${ }^{21}$ Efa Rodiah Nur. Op. Cit, hlm 10.

${ }^{22}$ Muslim bin al-Hajjaj Abû Husain Al-Qusyairi, Shahîh Muslim, Damaskus: Dar al-Fikr, 2005, hlm. 135.
} 
Volume 12, Nomor 2, April 2021

dalam keadaan butuh (hajat) yang tidak bisa dialihkan kecuali dengan kesulitan besar (dharurah)". 23

Bisnis yang dilakukan dengan sifatnya Gharar tersebut merupakan "bisnis yang tidak memenuhi perjanjian dan tidak dapat dipercaya, dalam keadaan bahaya, tidak diketahui harganya, barangnya, keselamatannya (kondisi barang), waktu memperolehnya. Bisnis Gharar yang diterjemahkan sebagai spekulasi disamakan dengan judi karena ketidakpastian kedua belah pihak (penjual dan pembeli). Praktik semacam ini banyak dilakukan oleh masyarakat modern, seperti jual beli hasil pertanian yang masih di lahan dengan sistem borongan. ${ }^{24}$ Apabila dikaitkan dengan ketentuan syarat sahnya perjanjian, sebagaimana diatur dalam pasal 1320 Kitab undang-Undang Hukum Acara Perdata, ketika perjanjian atau akad tersebut mengandung Gharar maka perjanian atau akad tersebut batal demi hukum. Dengan demikian antara yang melakukan transaksi tidak mengetahui batas-batas hak yang diperoleh melalui transaksi tersebut. Sedangkan dalam konsepsi fikih yang termasuk ke dalam jenis Gharar adalah membeli ikan dalam kolam, membeli buah-buahan yang masih mentah di pohon. Praktik Gharar ini, tidak dibenarkan salah satunya dengan tujuan menutup pintu lagi munculnya perselisihan dan perbuatan kedua belah pihak". ${ }^{25}$ Namun perlu diketahui bahwa ada pengecualian untuk membuat penjualan barang yang tidak terkirim menjadi halal. "Contohnya Quddamah berpendapat bahwa menjual ikan masih sah di laut jika ikan itu dimiliki (mamluk) dan airnya dangkal tempat ikan itu mungkin ditangkap. Dalam mendukung ini, sebuah studi oleh Rahman melihat bahwa pendapat ini lebih relevan dalam situasi saat ini dengan perkembangan teknologi modern yang mampu menangkap ikan dengan akurasi tinggi" ${ }^{26}$

Dari contoh tersebut Gharar telah diklasifikasikan ke dalam mayor (fahish) yaitu (Gharar sangat signifikan dan tidak ada alat untuk mengukur) dan minor (yasir) Gharar yaitu (Gharar tidak signifikan dan dapat diabaikan karena tidak menyebabkan perselisihan) dari alasan-alasan saat ini, hidup penuh dengan situasi di mana informasi kurang dan kadangkadang mustahil untuk dihindari tetapi dapat ditoleransi pada tingkat tertentu. ${ }^{27}$ Umumnya, Gharar dapat dibagi dalam dua kategori: "Pertama: Ditoleransi Gharar: Ditoleransi Gharar adalah Gharar yang dapat ditoleransi dan diterima oleh kedua belah pihak, dan tidak akan mempengaruhi esensi dari kontrak. Misalnya, beli mobil tertentu dari dealer yang akan dikirim minggu depan dengan harga yang disepakati sebesar Rp 100 juta. Meskipun mobil masih tidak ada hari ini (ketidakpastian ada), namun dealer akan memastikan bahwa mobil akan dikirimkan ke A pada saat disepakati. Dalam kasus hadis nabi yang melarang penjualan sesuatu yang tidak dimiliki oleh penjual, beberapa ahli hukum seperti Imam Ahmad bin Hanbal dan simpatisannya termasuk Ibn Taymiyyah dan Ibn al-Qayyim menafsirkan ketidakmampuan penjual untuk

\footnotetext{
${ }^{23}$ Efa Rodiah Nur. Op. Cit, hlm 11.

${ }^{24}$ Bani Maulana Syariif, "Perspektif Ekonomi Islam Tentang Bunga Uang: Sebuah Kajian Normatif Tentang Hutang-Piutang Dalam Perbankan Syariah", Himmah, 13.2 (2004), 34-47. hlm. 37.

${ }^{25}$ Riba Adiwarman Karim A, Oni Sahroni, Gharar Dan Kaidah-Kaidah Ekonomi Syariah: Analisis Fikih Dan Ekonomi, Jakarta: Raja Grafindo Persada, 2015, hlm. 58.

${ }^{26}$ Rahimah Embong Saidatoklama Mohd Yunus, Zuraidah Kamaruddin, 'Development of Modern Technology Capable of Catching Fish', International Journal of Academic Research in Business and Social Sciences, 18.11 (2018), 1-23. hlm. 4.

${ }^{27}$ Saidatoklama Mohd Yunus, Zuraidah Kamaruddin. Ibid, hlm. 7
} 
menyampaikan pokok pembicaraan. pada waktu yang disepakati. Para ahli hukum Islam sepakat bahwa itu mampu untuk ditoleransi dan diizinkan". ${ }^{28}$

"Kedua: Dilarangnya Gharar: dilarang Gharar adalah ketidakpastian yang begitu tinggi dan menguasai kontrak. Mungkin timbul karena pembeli atau penjual tidak mampu mengambil tanggung jawab. Hal ini ditekankan oleh Ibn Rushd bahwa Gharar berasal dari ketidaktahuan dan kurangnya informasi mengenai sifat dan atribut suatu objek, keraguan atas ketersediaan dan keberadaannya, keraguan atas kuantitas dan kualitasnya, atau keraguan tentang kuantitas dan kualitasnya, atau informasi yang pasti mengenai harga, unit mata uang di mana harga dibayar, dan ketentuan pembayaran. Ini juga terkait dengan waktu pembayaran dan pengiriman objek". 29

Berdasarkan uraian mengenai pengertian dari Gharar dari beberapa ahli sebagaimana yang telah tuliskan di atas, maka bisa disimpulkan bahwa terminologi Gharar yaitu suatu yang belum diketahui kepastiannya sehingga bisa menimbulkan kejahatan yang berupa penipuan. Sehingga apabila dibagi ke dalam unsur-unsurnya, terminologi Gharar tersebut memiliki 2 (dua) unsur yaitu belum pasti, sebagai unsur yang pertama dan kejahatan yang berupa penipuan sebagai unsur yang kedua. Apabila suatu transakasi bisnis khususnya transaksi bisnis Perbankan Syariah terbukti secara sah dan meyakinkan mengandung unsur belum pasti dan juga mengandung unsur penipuan maka sudah pasti transaksi bisnis Perbankan Syariah tersebut merupakan Gharar. Sehingga akibat hukumnya transaksi bisnis tersebut haruslah dinyatakan bertentangan dengan hukum, khususnya hukum Islam.

\section{Perspektif Hukum Islam Mengenai Praktik Gharar dalam Transaksi Perbankan Syariah Syariah di Indonesia}

Perlu diketahui dan disadari bersama bahwa Gharar bisa terjadi dalam segala jenis transaksi dalam bank-bank Syariah di Indonesia. Misalnya ketika keberadaan barang yang ditransaksikan di antara para pihak tidak atau setidaknya belum diketahu kepastiannya. Hal ini memungkinkan juga terjadi pada transaksi-transakasi yang dilakukan oleh para petani dengan pihak lain, misalnya pemberi pinjaman seperti bank, dikarenakan Petani belum mendapatkan kepastian mengenai hasil panennya. Berbeda dengan "kontrak salam, barang yang ditransaksikan meskipun tidak ada pada saat kontrak, namun kualitas dan kuantitas barang yang ditransaksikan jelas yang akan dikirimkan pada waktu yang disepakati". ${ }^{30}$

Transaksi bisnis yang belum pasti juga bisa terjadi pada "pembiayaan rumah yang digunakan terjadi dalam industri Perbankan Syariah Syariah di mana rumah itu masih dalam sengketa hukum yang menyebabkan perselisihan di antara para pihak di akhir kontrak atau di masa depan". ${ }^{31}$ Sehingga untuk bisa menghindari ketidak pastian dalam setiap transaksi bisnis, hal-hal yang penting untuk diperhatian antaralain: "Kejelasan status hukum barang yang

\footnotetext{
${ }^{28}$ Muhammad Imam Satra Mihajat, 'Contemporary Practice Riba, Gharar and Maysir in Islamic Banking and Finance', International Journal of Islamic Management and Business, 2.2 (2016), 1-19. hlm. 5.

${ }^{29}$ Muh. Fudhail Rahman, 'Nature and Gharar Limits In Maliyah Transactions', SALAM; Jurnal Sosial \& Budaya Syar-I, 5.3 (2018), 255-278. hlm. 256.

${ }^{30}$ Sirajul Arifin, 'Gharar Dan Risiko Dalam Transaksi Keuangan', Jurnal TSAQAFAH, 6.2 (2010), 312-224. hlm. 315.

31 Aldira Maradita, 'Karakteristik Good Corporate Governance Pada Bank Syariah Dan Bank Konvensional', Yuridika, 29.4 (2014), 190-203. hlm. 193.
} 
menjadi objek transaksi, kejelasan status kepemilikan barang yang akan ditransaksikan sebab Islam melarang penjualan barang atau barang di mana ia tidak memiliki kepemilikan atas barang yang akan menyebabkan perselisihan di masa depan dan harus pasti dalam hal barang yang ditransaksikan, jika itu adalah rumah, harus jelas dalam hal ukuran tanah, ukuran bangunan, lokasi dan spesifikasi bangunan. Jika itu adalah barang, harus jelas jenis barang dan spesifikasinya, dan jika itu adalah barang yang terkait dengan produk pertanian, maka diperbolehkan untuk melakukan kontrak salam di mana perincian produk yang dipesan harus ditentukan. dalam perjanjian pertama (berapa kilo, jenis atau kelas produk) serta waktu pengiriman". "Katakanlah jika itu adalah beras, harus jelas jenis beras apa yang akan dikirim di masa depan, apakah itu rojolele, pandan wangi atau jenis beras lainnya. Dari diskusi di atas, dapat disimpulkan bahwa setiap kontrak yang akan dilakukan di antara pihak-pihak yang berkontrak diperintahkan untuk memiliki transaksi yang jelas di tempat pertama dengan tujuan untuk menghindari kemungkinan perselisihan di masa mendatang yang dihasilkan dari ketidakpastian atas yang ditransaksikan. item dan ini bertujuan untuk melindungi pihak-pihak yang berkontrak dari kemungkinan pertengkaran di masa depan".32 Gharar dalam transaksi Perbankan Syariah bisa dipandang dari sistem bunga yang dibebankan pada setiap transaksi, baik dalam transaksi pinjaman maupun simpanan. Beban bunga yang ditetapkan adalah merupakan jenis Gharar yang mempertukarkan kewajiban antara satu pihak dengan pihak yang lain.

Sebagai negara dengan penduduk Islam terbanyak di dunia Indonesia memiliki potensi keuangan syariah yang sangat besar. ${ }^{33}$ Indonesia merupakan negara muslim terbesar dunia. Berdasarkan data Globalreligiusfuture, penduduk Indonesia yang beragama Islam pada 2010 mencapai 209,12 juta jiwa atau sekitar $87 \%$ dari total populasi. Kemudian pada 2020, penduduk muslim Indonesia diperkirakan akan mencapai 229,62 juta jiwa. ${ }^{34}$ "Indonesia memiliki peta jalan atau road map pengembangan pasar modal syariah, setidaknya bisa kita lihat ke dalam empat kelompok program yang akan dilakukan dalam pengembangan pasar modal syariah. Seperti, pengembangan regulasi yang mendukung perkembangan pasar modal syariah, pengembangan produk pasar modal syariah, pengupayaan kesetaraan produk pasar modal syariah dengan produk pasar modal konvensional, dan pengembangan sumber daya manusia di bidang pasar modal syariah. Program pertama, mengembangkan kerangka regulasi yang mendukung pengembangan pasar modal syariah. Beberapa regulasi terkait pasar modal syariah telah diterbitkan dalam beberapa tahun terakhir. Hal ini menjadi pijakan yang penting bagi pengembangan pasar modal syariah ke depan". ${ }^{35}$

\footnotetext{
${ }^{32}$ Ahmad Maulidizen, 'Riba, Gharar Dan Moral Ekonomi Islam Dalam Perspektif Sejarah Dan Komparatif: Satu

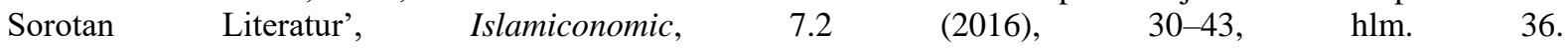
$<$ https://www.neliti.com/publications/255680/riba-Gharar-dan-moral-ekonomi-Islam-dalam-perspektif-sejarahdan-komparatif-satu>.

${ }^{33}$ Dien L. Purnamasari Iggi H. Achsien, 'Islamic Crowd-Funding as The Next Financial Innovation in Islamic Finance: Potential and Anticipated Regulation in Indonesia', EJIF -European Journal of Islamic Finance, 5.2 (2016), 1-12. hlm. 4.

${ }^{34}$ Viva Budy Kusnandar, 'Indonesia, Negara Dengan Penduduk Muslim Terbesar Dunia', Databooks, 2018 $<$ https://databoks.katadata.co.id/datapublish/2019/09/25/indonesia-negara-dengan-penduduk-muslim-terbesardunia> [accessed 8 March 2021].

${ }^{35}$ Ar Royyan Ramly. Op Cit. hlm. 8.
} 
Akan tetapi di setiap bidang bisnis akan mempunyai permasalahan nya sendiri-sendiri yang harus diselesaikan dengan melakukan penataan regulasinya. Pentingnya penataan regukasi dalam suatu bidang bisnis agar menjamin perlindungan hukum bagi setiap pelaku bisnis yang ada dalam bidang bisnis tersebut. Selain itu penetaan regulasi juga ditujukan agar bidang bisnis tersebut memiliki kejelasan dan ketegasan dalam setiap transaksi bisnisnya, sehingga setiap pelaku bisnis tersebut mendapatkan kepastian hukum. Hal ini dilakukan secara terus menerus yang dilakukan dengan menyesuaikan keadaan yang sedang terjadi, sehingga sifat hukum yang tidak pernah final itu terjadi dalam hal ini. Penataan regulasi harus terus menerus dilakukan. Semua bisnis memilikidinamika permasalahan yang beragam, sehingga perlu dilakukan penyempurnaan regulasi secara berkelanjutan. Pada praktik investasi di Indonesia, dimana didasarkan pada regulasi pasar modal syariah disusun secara jelas, sederhana, serta mendukung tumbuhnya kepercayaan investor terhadap kegiatan investasi pada pasar modal syariah. Pasar modal syariah merupakan kegiatan pasar modal yang tidak bertentangan dengan prinsip syariah di Pasar Modal. Pasar modal syariah memiliki 2 (dua) peran penting, yaitu: Sebagai sumberpendanaan bagi perusahaan untukpengembangan usahanya melalui penerbitan efek syariah. Sebagai sarana investasi efek syariah bagi investor. Pasar modal syariah bersifat universal, dapat dimanfaatkan oleh siapapun tanpa melihat latarbelakang suku, agama, dan ras tertentu. Pasar modal syariah merupakan bagian dari Industri Pasar Modal Indonesia. Secara umum, kegiatan pasar modal syariah sejalan dengan pasar modal pada umumnya. Namun demikian, terdapat beberapa karakteristik khusus pasar modal syariah yaitu bahwa produk dan mekanisme transaksi tidak boleh bertentangan dengan prinsip syariah di pasar modal.

Landasan Hukum Pasar modal Syariah secara umum sama dengan pengaturan tentang Pasar Modal di Indonesia, di antaranya mengatur tentang; "Pasar regulasi terkait pasar sekunder efek syariah dan juga regulasi terkait tata kelola pengawasan kepatuhan terhadap prinsip syariah (Shariah Compaliant). Program kedua, Pengembangan produk pasar modal syariah. Dinamika yang terjadi di industri keuangan global, telah menjadi bagian penting dari industri keuangan secara keseluruhan. Adapun strategi pengembangan produk syariah di pasar modal ke depan dapat dilakukan melalui dua pendekatan", yaitu; "Pertama, memperbanyak produk pasar modal syariah, sehingga kebutuhan sumber pendaanaan, sekaligus instrument investasi syariah, dapat dipenuhi. Kedua, menciptakan pilihan-pilihan produk baru yang belum ada sebagai sumber pendanaan bagi perusahaan. Langkah yang akan dilakukan untuk menerapkan dua pendekatan tersebut antara lain, menyusun pedoman baku produk syariah bagi perusahaan yang memerlukan pendanaan melalui pasar modal, mengkaji dan mengembangkan produk syariah melalui modifikasi produk pasar modal konvensional yang telah ada, serta menciptakan produk-produk syariah yang baru. Tujuan akhir dari strategi ini adalah menjadikan produk pasar modal syariah dalam industry keuangan menjadi semakin besar dan diharapkan dapat memberikan kontribusi yang cukup signifikan”.

"Ketiga, mengupayakan kesetaraan produk pasar modal syariah dengan produk konvensional. Produk syariah di pasar modal memiliki karakteristik khusus dibandingkan produk konvensional. Karakteristik tersebut terlihat dari proses transaksi, dan pembentukan produk harus memenuhi kaidah yang sesuai dengan prinsip syariah. Hal ini terkadang mengakibatkan adanya proses yang sedikit lebih rumit dibandingkan dengan produk 
konvensional. Di samping itu, dampak yang sering terjadi akibat dari karakteristik khusus tersebut adalah kewajiban terhadap pemenuhan regulasi tertentu terkadang menjadi lebih berat, seperti kewajiban terhadap aturan pajak. Hal ini tentunya mengakibatkan tidak setaranya kompetisi, antara produk syariah dengan produk konvensional. Untuk mengatasi persoalan ini diperlukan sebuah konsep penyetaraan antara produk syariah dengan produk konvensional. Tujuan dari kebijakan kesetaraan ini agar industri keuangan syariah dapat tumbuh dan berkembang secara alamiah sehingga akan lebih kokoh dibandingkan jika pertumbuhan tersebut dipicu oleh berbagai fasilitas dan insentif. Ke depan, kebijakan yang akan dilakukan adalah dengan mengupayakan aturan yang dapat menunjang konsep kesetaraan tersebut. Penyusunan dan penyempurnaan regulasi tersebut akan bersifat komprehensif, mulai dari penerbitan produk hingga kewajiban yang melekat setelah produk tersebut diterbitkan”. Juga mengupayakan kesetaraan perlakuan perpajakan antara produk keuangan syariah dengan produk keuangan konvensional.

"Keempat, Peningkatan sumber daya manusia (SDM) di pasar modal syariah. Ketersediaan SDM yang harus memenuhi kuantitas maupun kualitas, dipercaya akan mempercepat dan meningkatkan perkembangan industri pasar modal syariah di Indonesia. Juga diharapkan dapat meningkatkan inovasi-inovasi produk syariah di pasar modal. Kemudian, SDM yang berkualitas tentunya juga akan berdampak pada meningkatnya tingkat kepatuhan pada pemenuhan prinsip syariah. Keberadaan pasar modal syariah sangat penting, dan diperlukan guna terciptanya lembaga keuangan syariah yang lebih luas, karena keberadaan dan operasionalisasi Perbankan Syariah syariah akan kurang kondusif tanpa adanya dukungan dari berbagai lembaga keuangan lainnya. Selanjutnya, tujuan pasar modal syariah dapat disebutkan sebagai berikut: Pertama, memberi peluang investasi bagi masyarakat khususnya orang Islam. Keberadaan pasar modal syariah, jika demikian, bagai umat Islam khususnya dan semua orang pada umumnya, akan menjadi tempat untuk investasi, untuk secara riil ikut menempatkan uangnya dalam alokasi produksi, yang hal itu merupakan kunci dari penggerakan sektor ekonomi. Kedua, bahwa keberadaan pasar modal syariah ini, dari sisi lain, akan menjadi sebuah alternatif atau jalan keluar bagi pasar modal konvensional, dan bagi investor yang ingin beralih ke pasar modal syariah dengan memilih produk yang hala dan terjamin". ${ }^{36}$

Berbicara mengenai alternatif sistem, bank syariah menjadi alternatif yang halal bagi transaksi bisnis, selain itu bank syariah juga menjadi alternatif yang aman dalam transaksi bisnis. Berbagai goncangan ekonomi global maupun goncangan ekonomi nasional yang terjadi di Indonesia, mampu diatasi oleh bank syariah, hal ini membuktikan kualitas bank syariah sebagai tempat bertransaksi yang aman dan terpecaya. Ketiga, mendorong pelaku bisnis, untuk menjalankan bisnisnya dengan berlandaskan pada ajaran hukum Islam. Hal utama yang menjadi pembeda antara bank konvensional dan bank syariah adalah ada atau tidaknya unsur yang bersifat spekulatif, yang disebut Gharar. Implementasi konsep Gharar dalam melakukan seleksi terhadap bentuk-bentuk teransakasi di Indonesia menarik untuk diketahui. Di samping untuk mengetahui hal tersebut, konsep Gharar merupakan bentuk penegakan ajaran hukum Islam yang baik. Pada era modern seperti saat ini, keseluruhan instrumen transaksi investasi yang ditawarkan berupa; saham dan obligasi dalam varian yang terbatas, dan belum sampai

\footnotetext{
${ }^{36}$ Hasanudin Maulana, 'Multiakad Dalam Transaksi Syariah Kontemporer Pada Lembaga Keuangan Syariah Di Indonesia', Al-Iqtishad, 3.1 (2011), 150-168. hlm. 157.
} 
pada berbagai variasi surat berharga dari sukuk atau bond sebagaimana yang sebagian negara pengembang bisnis keuangan syariah menerapkannya. Pada tingkatan tertentu, hal ini patut diduga terkait dengan konsep Gharar dan implementasinya dalam tataran praktik guna screening pasar modal.

"Imam Al-qarafi disebutkan dalam buku Muhammad Nafik mendefinisikan Gharar dalam investasi sebagai suatu akad yang tidak diketahui dengan tegas, sedangkan Ibnu Taimiyah menyebutkan adalah ketidakpastian yang disebabkan oleh suatu akad. Oleh sebab itu tidak semua Gharar bermakna tipuan atau tindakan merugikan orang lain. Ketidakpastian dalam memperoleh return dalam investasi tidak termasuk Gharar maupun maysir, karena hal itu termasuk kosekuensi investasi. Perjudian (maysir) dianggap haram salah satunya mengganggu sistem perekonomian, perjudian dalam bentuk uang akan mengakibatkan uang tersebut hanya beredar dikalangan penjudi dengan tidak melakukan aktivitas ekonomi apapun yang mengubah fungsi uang sebagai alat tukar, alat mengukur nilai, menyimpan nilai berubah menjadi alat spekulasi". 37

Gharar mengakibatkan aktivitas bisnis terganggu, investasi yang dilakukan dengan mengutamakan keuntungan namun belum ada kejelasan bntuk transaksinya, ketidakpastian itu terjadi dari segi kualitas, kuantitas, atau waktu perolehan maka yang seperti ini disebut sebagai Gharar. Bentuk ketidakpastian dalam aktivitas bisnis di bidang Perbankan Syariah yaitu praktik seperti short selling. Praktik short selling merupakan pihak yang meminjamkan sekuritas atau efek mendapat ketidakpastian, sehingga besarnya nilai sekuritas yang diterima dari peminjam didasarkan atas harga saat pengembalian, bukan saat meminjam. Pihak peminjam beruntung apabila harganya turun dan merugi jika harganya naik. Gharar dalam bentuknya yang lain seperti obligasi dengan sistem bunga. Praktik tersebut pada tingkat pengembalian (fixed income) yang berupa bunga artinya terjadi ketidakpastian dalam hal kuantitas return.

\section{PENUTUP}

Perspektif Hukum Islam menyatakan bahwa Gharar wajib dihindari pada praktik Perbankan Syariah di Indonesia hal ini dikarenakan Gharar akan mengakibatkan semua akad bisnis hanya berorientasi keuntungan semata atau profit oriented, dan mengabaikan rasa keadilan para pihak. Gharar berkaitan erat dengan suatu risiko yang dihadapi oleh transaksi bisnis pada umumnya dan transaksi bisnis di bidang Perbankan Syariah di Indonesia pada khususnya. Gharar adalah suatu keadaan yang uncomplete information karena tidak adanya informasi yang jelas, di antara para pihak yang melakukan akad transaksi bisnis. Hal semacam ini haram hukumnya dalam ajaran hukum Islam, namun meskipun dilarang dalam fikih Gharar dimaklumi jika, beberapa kriteria berikut terpenuhi yaitu; dilakukan pada keadaan butuh (hajat) yang tidak bisa dialihkan kecuali dengan kesulitan besar(dharurah) dan dilakukan jika untuk mewujudkan sistem transaksi yang baik menurut ajaran hukum IslamIslam, perlu dukungan dari umat Islam, yaitu dengan menerapkan konsep investasi dalam Islam. Di dalam konsep itu telah dibangun cara-cara agar hati-hati dalam bertransaksi dan menghindari hal-hal yang

\footnotetext{
${ }^{37}$ Rita Indah Mustikowati Agus Syahnanda Hasibuan, R. Anastasia Endang Susilawati, 'Analisis Pelaksanaan Profit-Loss Sharing Pada Akad Mudharabah Di Bank Syariah Mandiri', Jurnal Riset Mahasiswa Akuntansi, 4.2 (2016), 1-14. Hlm. 5. 〈http://ejournal.unikama.ac.id/index.php/jrma/article/view/1388\%0A〉.
} 
Dialogia luridica: Jurnal Hukum Bisnis dan Investasi

Volume 12, Nomor 2, April 2021

dilarang oleh Islam, hal inilah yang merupakan persperktif hukum Islam mengenai praktik Gharar dalam transaksi di bidang Perbankan Syariah di Indonesia.

\section{DAFTAR PUSTAKA}

\section{Buku}

Adiwarman Karim A, Oni Sahroni, Riba, Gharar Dan Kaidah-Kaidah Ekonomi Syariah: Analisis Fikih Dan Ekonomi, Jakarta: Raja Grafindo Persada, 2015.

Galang Taufani, Suteki, Metodologi Penelitian Hukum (Filsafat, Teori, Dan Praktik), Depok: Rajawali Pers, 2017.

Ismail, Perbankan Syariah, Jakarta: Kencana, 2011.

Zubairi Hasan, Undang-Undang Perbankan Syariah Titik Temu Hukum Islam Dan Hukum Nasional, Jakarta: PT Raja Grafido Persada, 2009.

\section{Jurnal}

Agus Santoso, Dyah Pratiwi, 'Tanggung Jawab Penyelenggara Sistem Elektronik Perbankan Dalam Kegiatan Transaksi Elektronik Pasca Undang-Undang Nomor 11 Tahun 2008 Tentang Informasi Dan Transaksi Elektronik', Jurnal Legislasi, 5.4 (2018).

Agus Syahnanda Hasibuan, R. Anastasia Endang Susilawati, Rita Indah Mustikowati, 'Analisis Pelaksanaan Profit-Loss Sharing Pada Akad Mudharabah Di Bank Syariah Mandiri', Jurnal Riset Mahasiswa Akuntansi, $4.2 \quad$ (2016), 1-14 <http://ejournal.unikama.ac.id/index.php/jrma/article/view/1388\%0A>.

Al-Qusyairi, Muslim bin al-Hajjaj Abû Husain, Shahîh Muslim (Damaskus: Dar al-Fikr, 2005) Al-Zuhayli, Wahbah, Al-Fiqh Al-Islami Wa Adillatuh, Juz 5 (Damaskus: Dar al-Fikr, 2004).

Ali Mansyur, Irsan Rahman, 'Penegakan Hukum Perlindungan Konsumen Sebagai Upaya Peningkatan Mutu Produksi Nasional', Jurnal Pembaharuan Hukum, 2.1 (2015).

Amaroh, Siti, 'Tanggung Jawab Sosial Bank Syariah Terhadap Stakeholder Dalam Perspektif Maqâshid Syarî'ah', Ahkam, 16.1 (2016).

Arifin, Sirajul, 'Gharar Dan Risiko Dalam Transaksi Keuangan', Jurnal TSAQAFAH, 6.2 (2010).

Hendro Nugroho, 'Perlindungan Hukum Bagi Para Pihak Dalam Transaksi Pinjaman Online', JUSTITIA: Jurnal Ilmu Hukum Dan Humaniora, 7.2 (2020).

Hosen, Nadratuzzaman, 'Analisis Bentuk Gharar Dalam Transaksi Ekonomi', Al-Iqtishad, 1.1 (2009).

Iggi H. Achsien, Dien L. Purnamasari, 'Islamic Crowd-Funding as The Next Financial Innovation in Islamic Finance: Potential and Anticipated Regulation in Indonesia', EJIF -European Journal of Islamic Finance, 5.2 (2016).

Ishak, Ajub, 'Posisi Hukum Islam Dalam Hukum Nasional Di Indonesia', Jurnal Al-Qadau, 4.1 (2017).

Khairunisa, Putri Nova, 'Etika Bisnis Dalam Islam Terhadap Transaksi Terlarang Riba Dan Gharar', LABATILA: Jurnal Ilmu Ekonomi Islam, 3.1 (2019).

Kornelius Benuf, Rinitami Njatrijani, Ery Agus Priyono, Nur Adhim, 'Pengaturan Dan Pengawasan Bisnis Financial Technology Di Indonesia', Dialogia Iuridica: Jurnal Hukum Bisnis Dan Investasi, 11.2 (2020). 
Kornelius Benuf, 'Urgensi Kebijakan Perlindungan Hukum Terhadap Konsumen Fintech Peer To Peer Lending Akibat Penyebaran Covid-19', Jurnal RechtsVinding, 9.2 (2020).

Kornelius Benuf, Muhamad Azhar, 'Metodologi Penelitian Hukum Sebagai Instrumen Mengurai Permasalahan Hukum Kontemporer', Jurnal Gema Keadilan, 7.1 (2020).

Maradita, Aldira, 'Karakteristik Good Corporate Governance Pada Bank Syariah Dan Bank Konvensional', Yuridika, 29.4 (2014).

Maulana, Hasanudin, 'Multiakad Dalam Transaksi Syariah Kontemporer Pada Lembaga Keuangan Syariah Di Indonesia', Al-Iqtishad, 3.1 (2011).

Maulidizen, Ahmad, 'Riba, Gharar Dan Moral Ekonomi Islam Dalam Perspektif Sejarah Dan Komparatif: Satu Sorotan Literatur', Islamiconomic, 7.2 (2016), 30-43 $<$ https://www.neliti.com/publications/255680/riba-gharar-dan-moral-ekonomi-islamdalam-perspektif-sejarah-dan-komparatif-satu>.

Mihajat, Muhammad Imam Satra, 'Contemporary Practice Riba, Gharar and Maysir in Islamic Banking and Finance', International Journal of Islamic Management and Business, 2.2 (2016).

Muchtar, Evan Hamzah, 'Muamalah Terlarang: Maysir Dan Gharar', Jurnal Asy-Syukriyyah, 18.2 (2017).

Muzdalifa, Irma, Inayah Aulia Rahma, and Bella Gita Novalia., 'Peran Fintech Dalam Meningkatkan Keuangan Inklusif Pada UMKM Di Indonesia (Pendekatan Keuangan Syariah)', Jurnal Masharif Al-Syariah: Jurnal Ekonomi Dan Perbankan Syariah, 3.1 (2018).

Nur, Efa Rodiah, 'Riba Dan Gharar: Suatu Tinjauan Hukum Dan Etika Dalam Transaksi Bisnis Modern', Jurnal AL- 'ADALAH, 12.3 (2015).

Rahman, Muh. Fudhail, 'Nature and Gharar Limits In Maliyah Transactions', SALAM; Jurnal Sosial \& Budaya Syar-I, 5.3 (2018).

Ramly, Ar Royyan, 'The Concept of Gharar and Masyir and It's Application to Islamic Financial Institutions', International Journal of Islamic Studies and Social Sciences, 1.1 (2019).

Saidatoklama Mohd Yunus, Zuraidah Kamaruddin, Rahimah Embong, 'Development of Modern Technology Capable of Catching Fish', International Journal of Academic Research in Business and Social Sciences, 18.11 (2018).

Syariif, Bani Maulana, 'Perspektif Ekonomi Islam Tentang Bunga Uang: Sebuah Kajian Normatif Tentang Hutang-Piutang Dalam Perbankan', Himmah, 13.2 (2004).

Viva Budy Kusnandar, 'Indonesia, Negara Dengan Penduduk Muslim Terbesar Dunia', Databooks, $2018<$ https://databoks.katadata.co.id/datapublish/2019/09/25/indonesianegara-dengan-penduduk-muslim-terbesar-dunia> [accessed 8 March 2021]. 